
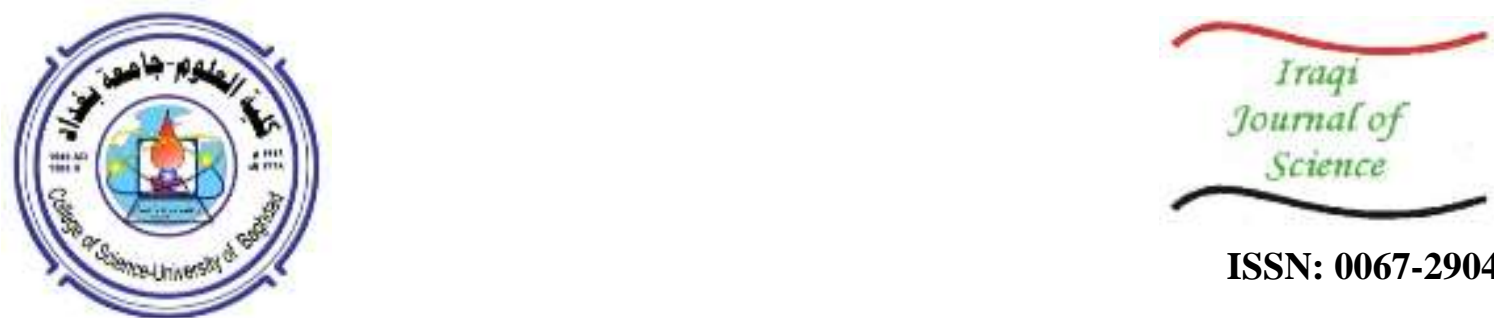

ISSN: 0067-2904

\title{
Biochemical Tests as an Indicator for the Effects of Electrical Generator Exhausts on Human Health
}

\author{
Inaam Noori Ali, Hayder G. Jawad, Rahafat R. Mohammad \\ Ministry of Science and Technology, Environment and water Directorate, Centre of pollutants Treatment
}

Received: 7/11/2020

Accepted: $24 / 5 / 2021$

\begin{abstract}
Diesel generators are used in various locations throughout Baghdad city, central Iraq, when the public electricity power is in outage. The main purpose of the current research is to investigate possible changes in certain biochemical parameters in the blood of operators of diesel generators in different locations Baghdad city, at both Rusafa and Karkh sides. The workers were divided according to the number of working years.

Serum urea, creatinine, alkaline phosphatase (AlP), aspartate aminotransferase (AST), alanine aminotransferase (ALT), albumin, total serum bilirubin (TSB), and glomerular filtration rate (GFR) were analyzed in samples from forty workers and compared with ten healthy persons as a control group. The findings revealed a substantial reduction in the amounts of creatinine and albumininine $(\mathrm{p}<0.01)$ and the value of GFR, while the levels of AlP, AST, ALT, and TSB recorded a significant increase in the sera of the workers compared with the control group. Differences in the serum levels of urea were statically insignificant.

The temporal analysis also showed that the continuous work in the generators' locations for many years causes disorders in the biochemical parameters in the blood of workers.
\end{abstract}

Keywords: Biochemical blood parameters, diesel electric generators, Baghdad city.
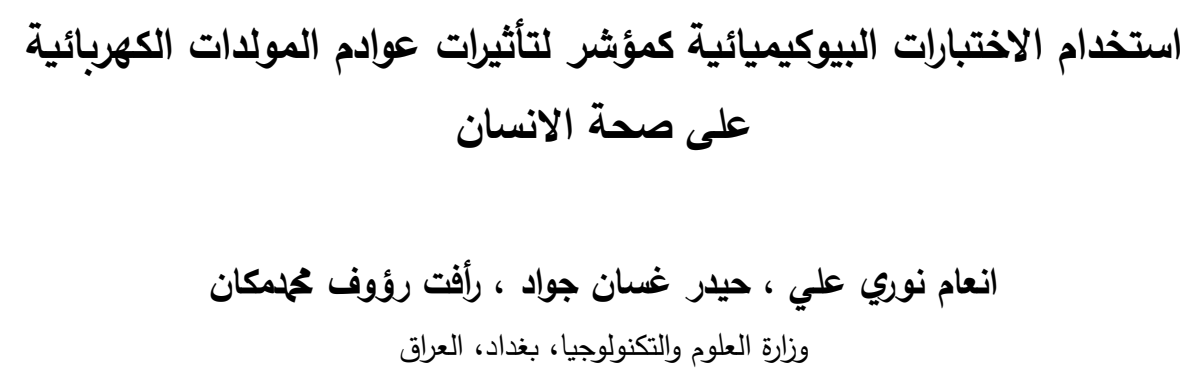

تستخدم مولدات الديزل في مواقع بغداد في حالة انقطاع الكهرباء. كان الغرض الرئيسي من البحث

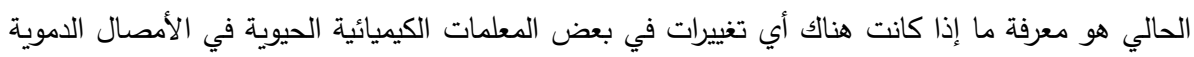

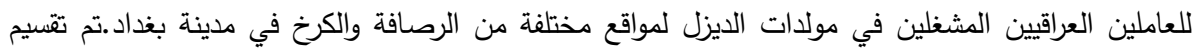

العاملين حسب فترة اشتغالهم في المولدات.

*Email: inaambio@gmail.com 


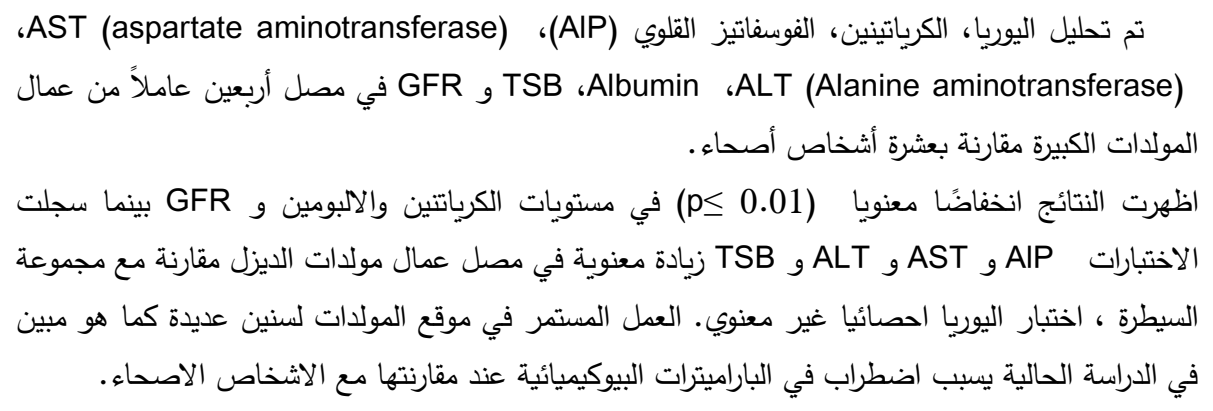

\section{Introduction}

The utilization of generators of various types is a common practice in almost all the cities of Iraq. This practice occurs due to the great decrease in the supply of electricity produced in power plants throughout the country due to the effects of wars that caused the devastation of the national electricity system.

The running of generators causes two main types of pollution. The first is air pollution that is caused by the use of two types of fuel to run generators (gasoline and diesel). The exhaust fumes produced by these generators contain many toxic substances, such as hydrocarbons, carbon oxides, sulfur oxides, benzo(a)pyrene, nitrogen oxides, particulates, fluorides, and heavy elements, especially lead, all of which have a variety of damages to public health, animals, plants, and environmental life [1,2].

The second type is water pollution with oil and its derivatives during the operation of generators. It also involves contamination of soil and plants by fuel leaks as well as the waste produced upon the maintenance of generators [3]. Aromatic hydrocarbons (AHs) are the sole of the diesel vapor caused by generators. These compounds exert their poisoning impacts through the formation of mutagenic AH-DNA complexes [4].

Products of petroleum fumes might be converted in the body to different metabolites, which can interact with metabolites in the liver and kidney to evolve toxic effects that lead to cell damage and, consequently, tissue deterioration [5]. When the kidney tissue is disrupted, its functions will be compromised. In addition, air pollutants, especially the particulate matter (PM), have been strongly associated with adverse effects on the respiratory and cardiovascular health, with a possible consequence of mortality [6].

Also, the reverse effects of exhaust pollutants include increased mortality of infants, acute heart attacks, chronic deficits in lung development of people aged 10-18 years, and ovarian cancer. Various epidemiological studies have also shown that exposure to huge amounts of petroleum related particles leads to an increase in the rates of diseases and death [7]. The current study aims to evaluate of biochemical parameters for workers in electrical generators in different sites of Baghdad city as an indicators for human health..

\section{Materials and Methods}

\section{Study site}

This study was carried out in different locations of diesel generators in Baghdad city (both Rusafa and Karkh sides) during the period of April to August 2019. The studied sites included Al-Saydiyah, Hay Aljihad, Alghazalya, Al-Kadhimiya, Alkarada, and Alhuriya (Table 1).

Table 1- Locations of selected diesel generator stations in Baghdad city along with the number of workers

\begin{tabular}{|c|c|c|}
\hline Site & $\begin{array}{c}\text { No. of } \\
\text { Workers }\end{array}$ & Control group \\
\hline Hay Aljihad- Hay Alhussien & 3 & - \\
\hline Hay Aljihad- Al-Taie Aquare & 1 & 1 \\
\hline Hay Aljihad-Al-Alpheen & 4 & 1 \\
\hline Al-Saydiyah - Near Alhuda Mosque & 5 & 1 \\
\hline
\end{tabular}




\begin{tabular}{|c|c|c|}
\hline Al-Saydiyah - The Martyrs Of Saydiyah & 4 & 1 \\
\hline Al-Kadhimiya- Sixty Street & 3 & 1 \\
\hline Al-Kadhimiya- Al-Bahaya Area & 2 & 1 \\
\hline Al-Kadhimiya- Akad Street & 3 & 1 \\
\hline Al-Kadhimiya- Habnah Area & 2 & - \\
\hline Al-Ghazaliya Area & 5 & 1 \\
\hline The Third Al-Huriya & 5 & 1 \\
\hline Al- Karrada- Sarah Camp & 3 & 1 \\
\hline Total & $\mathbf{4 0}$ & $\mathbf{1 0}$ \\
\hline
\end{tabular}

\section{Divisions of workers}

Based on the number of years of work in diesel generators, the 40 working people were divided into group A (23 worker), with a period of work of less than 10 years, and group B (17 worker), with a period of work of more than 10 years. The study also involved 10 healthy volunteers as a control group. The age range of the participants was 20-60 years. A questionnaire form was prepared before sampling which included information on age, residence, occupation, working hours, marital status, number of children, weight, and others. Workers having a history of present or previous illness, as well as those who are smokers and alcoholics, were excluded (Table 2).

Table 2-Distribution of workers according to the period of working in diesel generators

\begin{tabular}{|c|c|c|}
\hline Group & Duration of work & No. of workers \\
\hline A & Less than $10(1-9)$ years & 23 \\
\hline B & More than $10(10-14)$ years & 17 \\
\hline Total & & $\mathbf{4 0}$ \\
\hline
\end{tabular}

\section{Samples Collection}

Five $\mathrm{ml}$ of blood was obtained from each individual by vein puncture; for the tests of biochemical parameters, $4 \mathrm{ml}$ of blood was placed into plain disposable tubes, then allowed to clot in $37 \mathrm{C}^{0}$ for $10-15$ minutes and centrifuged at 300 RPM for approximately 10-15 minutes. For hematological tests, $1 \mathrm{ml}$ of blood was kept in EDTA tubes [8].

\section{The Biochemical parameters}

The serum was obtained and stored at $-20 \mathrm{C}^{0}$ until analysis to measure several parameters. Creatinine and urea were estimated by using kits of kinetic colorimetric method (Linear Company, SPAIN), while alkaline phosphatase was determined quantitatively by kits from BIOLABO Company. Enzymes levels (ALT and AST) were measured by using a colorimetric spectrophotometer (Cromatest, Linear company) at 405 and $340 \mathrm{~nm}$, respectively. Albumin and total serum bilirubin were assayed by a colorimetric method using specific kits (Linear company). [8].

The glomerular filtration rate (GFR) was measured according to the Modification of Diet in Renal Disease (MDRD) calculation formula, as follows [9]:

$\mathrm{GFR}=140 \times(\mathrm{Scr} / \kappa, 1) \min \alpha \times(\mathrm{Scr} / \kappa, 1) \max -1.209 \times$ Age $0.993 \times 1.018$ [female] $\_1.159$ [black].

where Scr is creatinine, $\kappa$ is constant ( 0.9 for men and 0.7 for women), min marks the lower rate of Scr/ $/$ or 1 , max marks the upper rate of $\mathrm{Scr} / \kappa$ or $1, \alpha$ is a factor that has a value of 0.411 for males and -0.328 for females [9].

\section{Results and discussion}

Human exposure to diesel fumes is associated with multiple toxicities affecting the hepatic, immunologic, hematological, and chromosomal functions, in addition to an increased risk of carcinogenesis. This study tried to find the possible alterations in biochemical and hematological parameters of workers with diesel generators. The tests were conducted on 
forty diesel generator workers from different regions and 10 normal men. The workers were divided according to the number working years.

The results of biochemical parameters for workers were studied and compared with the control group, as shown in Table 3.

Table 3-Results of biochemical parameters tested in serum samples from workers in diesel generators and control in Baghdad City, Iraq

\begin{tabular}{|c|c|c|c|c|}
\hline Parameter & $\begin{array}{c}\text { Workers } \\
\text { group }(\mathrm{N}=40)\end{array}$ & $\begin{array}{c}\text { Control } \\
\operatorname{group}(\mathbf{N}=10)\end{array}$ & T-test & $P$ value \\
\hline Creatinine $\mathrm{mg} / \mathrm{dl}$ & $0.872 \pm 0.03$ & $0.760 \pm 0.02$ & $0.1014 *$ & 0.0438 \\
\hline Urea $\mathrm{mg} / \mathrm{dl}$ & $38.77 \pm 0.64$ & $36.50 \pm 0.85$ & $2.744 \mathrm{NS}$ & 0.102 \\
\hline $\mathrm{AlP} \mathrm{Iu} / \mathrm{L}$ & $48.71 \pm 1.71$ & $85.79 \pm 6.79$ & $27.568 * *$ & 0.0094 \\
\hline AST U/L & $16.90 \pm 1.38$ & $33.27 \pm 3.30$ & $13.477 * *$ & 0.0108 \\
\hline ALT U/L & $16.03 \pm 1.28$ & $31.44 \pm 3.99$ & $12.221 *$ & 0.052 \\
\hline TSB mg/dl & $0.320 \pm 0.05$ & $0.748 \pm 0.08$ & $0.336 * *$ & 0.0103 \\
\hline Albumin g/dl & $4.28 \pm 0.11$ & $3.84 \pm 0.08$ & $0.358 * *$ & 0.0107 \\
\hline GFR $\mathrm{ml} / \mathrm{min} / 1.73 \mathrm{~m}^{2}$ & $119.30 \pm 4.32$ & $103.85 \pm 3.52$ & $14.875 *$ & 0.0421 \\
\hline
\end{tabular}

* Significant difference at $\mathrm{P} \leq 0.05, * *$ significant difference at $\mathrm{P} \leq 0.01, \mathrm{NS}$ : Non-Significant.

Figure 1 shows the levels of creatinine in the serum of the workers at different durations of work (groups A and B), which indicated highly significant differences compared with the control. As related to urea, the results in Figure 2 show that the serum urea levels increased from $37.83 \mathrm{mg} / \mathrm{dl}$ in the control group to $38.77 \mathrm{mg} / \mathrm{dl}$ in workers with less than 10 years duration of work. While, for workers with more than 10 years duration of work, the level of urea was higher $(40.06 \mathrm{mg} / \mathrm{dl})$. From the present results, it is clear that the prolonged duration of work leads to higher urea levels. The function of the kidney is the excretion of metabolic waste (urea and creatinine) and organization of water and electrolyte balance. Abnormal concentrations of these metabolic waste products in the blood is an evidence of failure in renal function [10].

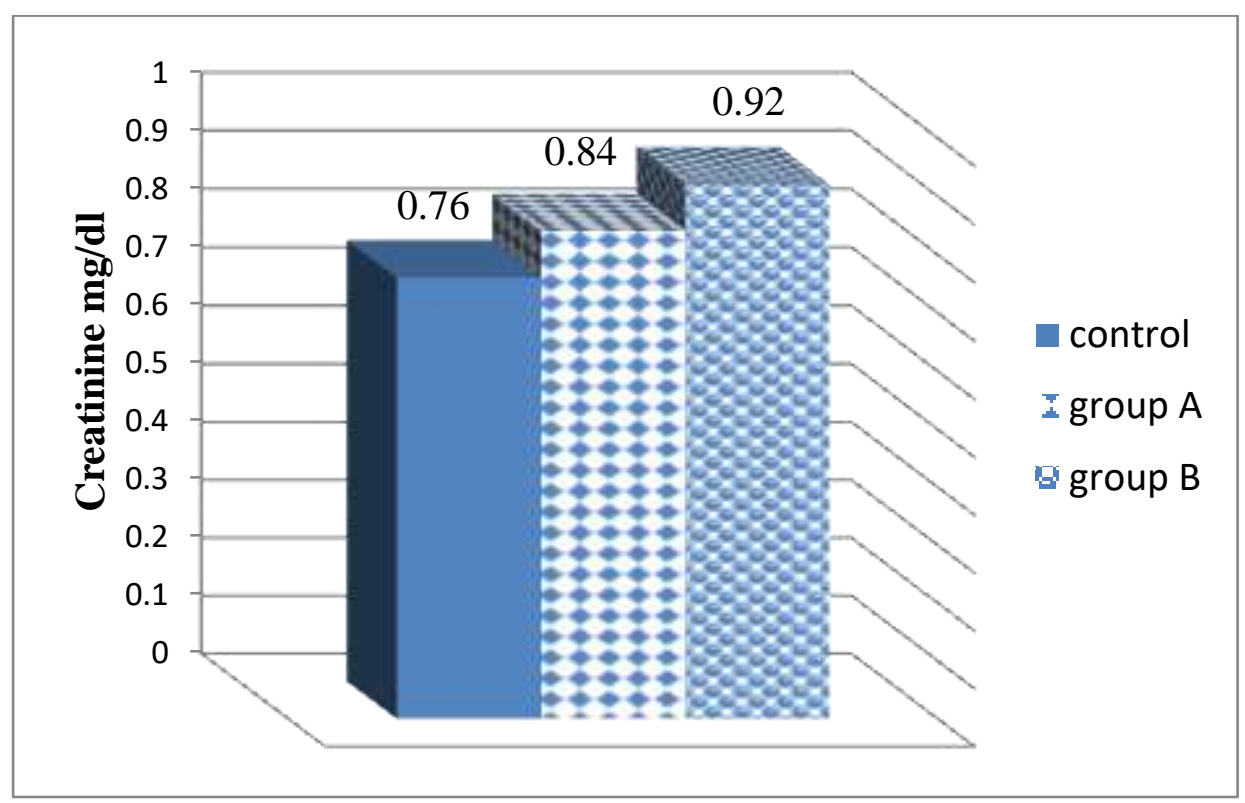

Figure 1-Comparisons in the serum urea levels between workers with different working durations in diesel generators(more and less 10 years) and the control group in Baghdad City, Iraq 


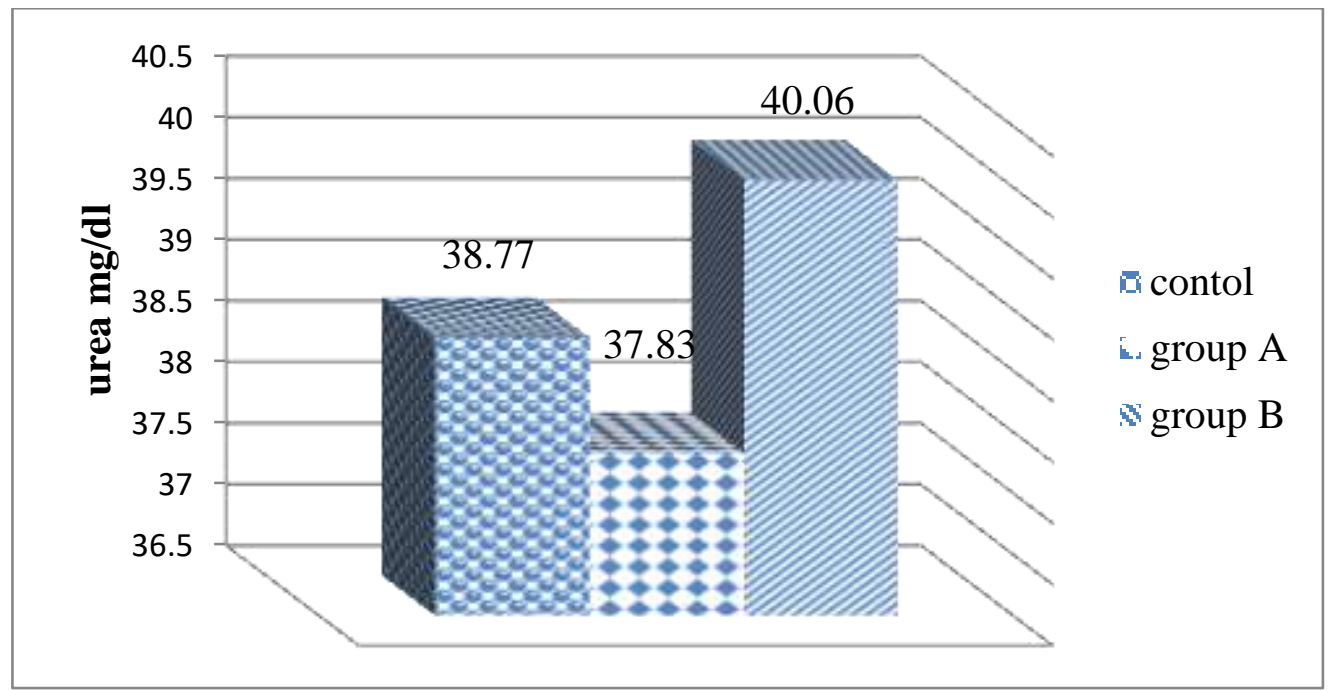

Figure 2- Comparisons in the serum creatinine levels between workers with different working durations in diesel generators and the control group in Baghdad City, Iraq

Impairment of the renal function may be caused by exposure to different nephrotoxic substances. Nephrotoxicity is related to the exposure to heavy metals, such as lead, emitted from generators or car exhaust [11]. Ueng et al. [12] reported time and dose dependent increase in glutathione S-transferase and cytochrome P-450-dependent monooxygenase in the lung microsomes, kidney, and liver of rats exposed to organic and particulate matter from motorcycle exhaust. These enzymes are known to convert the polycyclic aromatic hydrocarbons PAHs to polar nucleophilic compounds that interact with certain bases of DNA (adenine and guanine).

Moreover, the serum levels of AlP, AST , TSB and albumin were significantly higher ( $\mathrm{P}<$ $0.01)$, while those of GPT and GFR were significantly different $(\mathrm{P}<0.05)$ as compared with the control group (Table 3 ).

The results in Figure 3 also show noticeable differences in the serum levels of AlP among the studied groups. Workers in group A had significantly decreased levels as compared with the control group, while in group B, the levels were higher as compared to the control. The prolonged exposure to generator fumes allows particulate matter to attack the liver and cause Kupffer cell activation, inducing an inflammatory response and an increase in AlP activity [13].

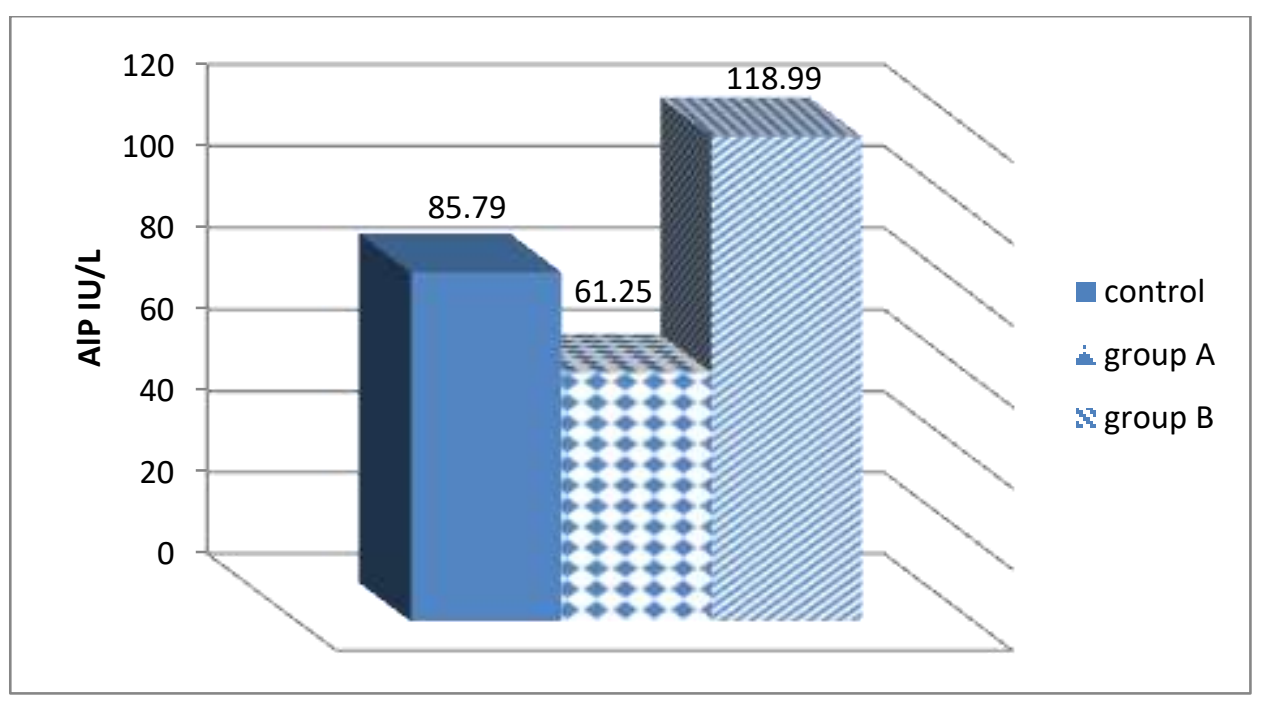

Figure 3-Comparisons in the AlP levels between workers with different working durations in diesel generators and the control group in Baghdad City, Iraq 
Figures 4 and 5 show the comparisons in the AST and ALT levels between workers with different working durations in diesel generators and the control group. The levels were significantly decreased in group B, while they were significantly increased in group A, as compared with the control group.

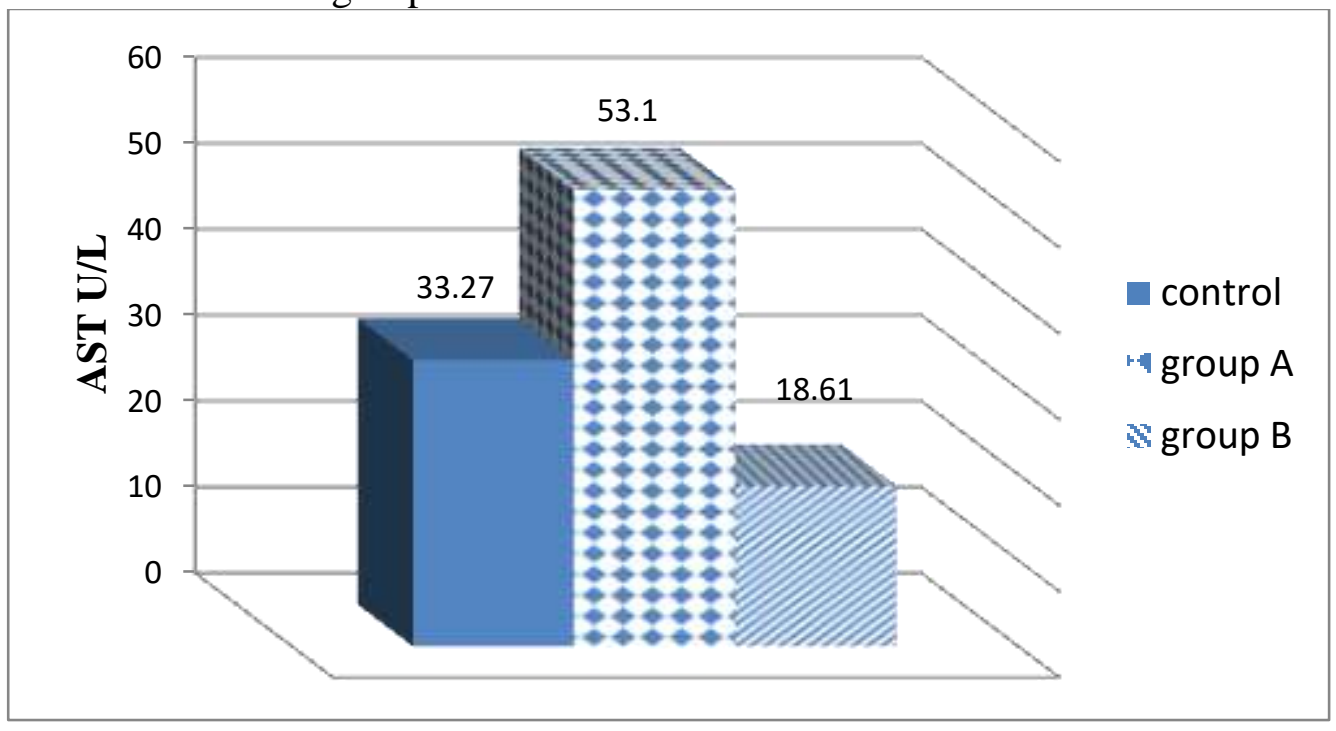

Figure 4-Comparisons in the AST levels between workers with different working durations in diesel generators and the control group in Baghdad City, Iraq

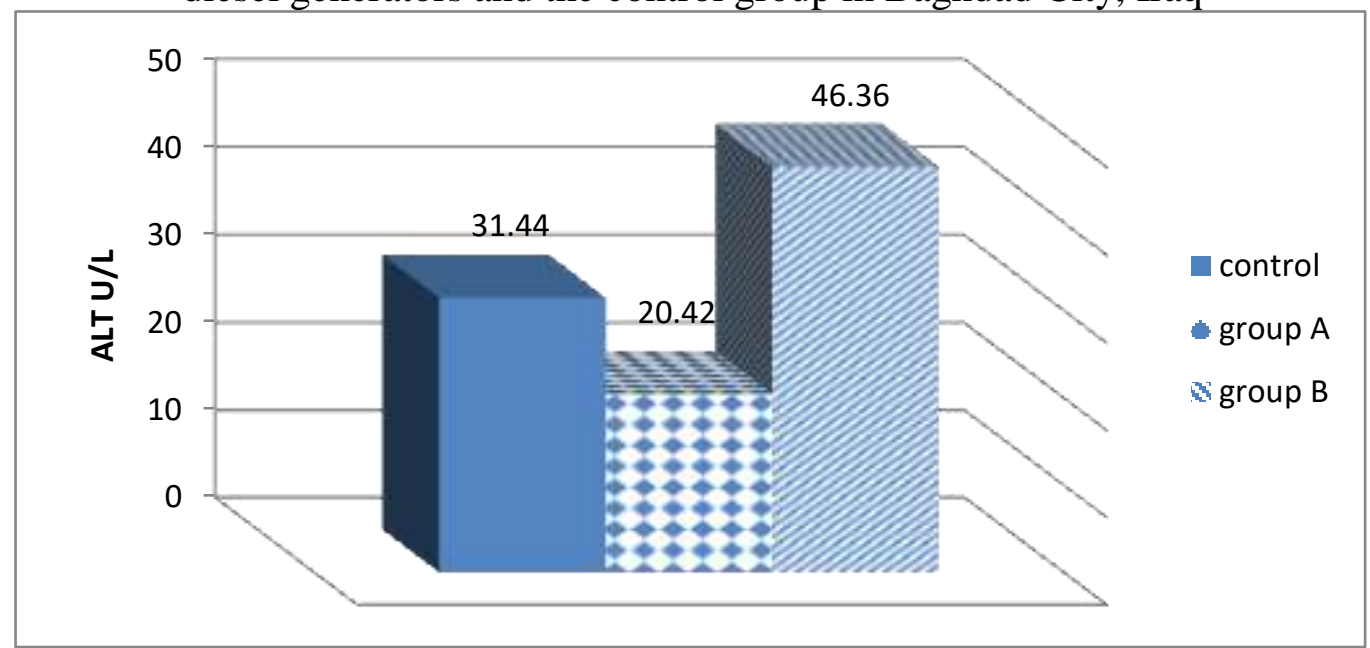

Figure 5-Comparisons in the ALT levels between workers with different working durations in diesel generators and the control group in Baghdad City, Iraq

The mitochondrial enzyme AST is found in the liver, plasma, kidney, skeletal muscle, and heart. Its elevated level in the serum leads to disturbance of mitochondrial membrane, elevation in intracellular $\mathrm{Ca}^{+2}$, and generation of reactive oxygen species (ROS). All of these impacts represent cytotoxic mechanism that can be induced by exhaust emissions [14]. Altered levels of ALT are a particular indicator of liver damage, since this enzyme is found in large quantities in the cystol of the hepatic cells, whereas it has a low quantity in other organs. The increased levels of ALT found in the present study can be attributed particularly to the liver cell damage caused by the exhausts produced by the generators of electricity [15].

Furthermore, the results in Figure 6 display the highly significant decrease in group A and the highly significant increase in group B in the mean level of TSB in the sera of Iraqi diesel generator operators, compared with the control group $(\mathrm{p}<0.01)$. Polycyclic aromatic hydrocarbons are compounds that exist naturally in crude oil, gasoline, and generator vapor. 
These compounds are metabolized quickly to large quantities of 1- hydroxypyrene in the blood $[4,16]$.

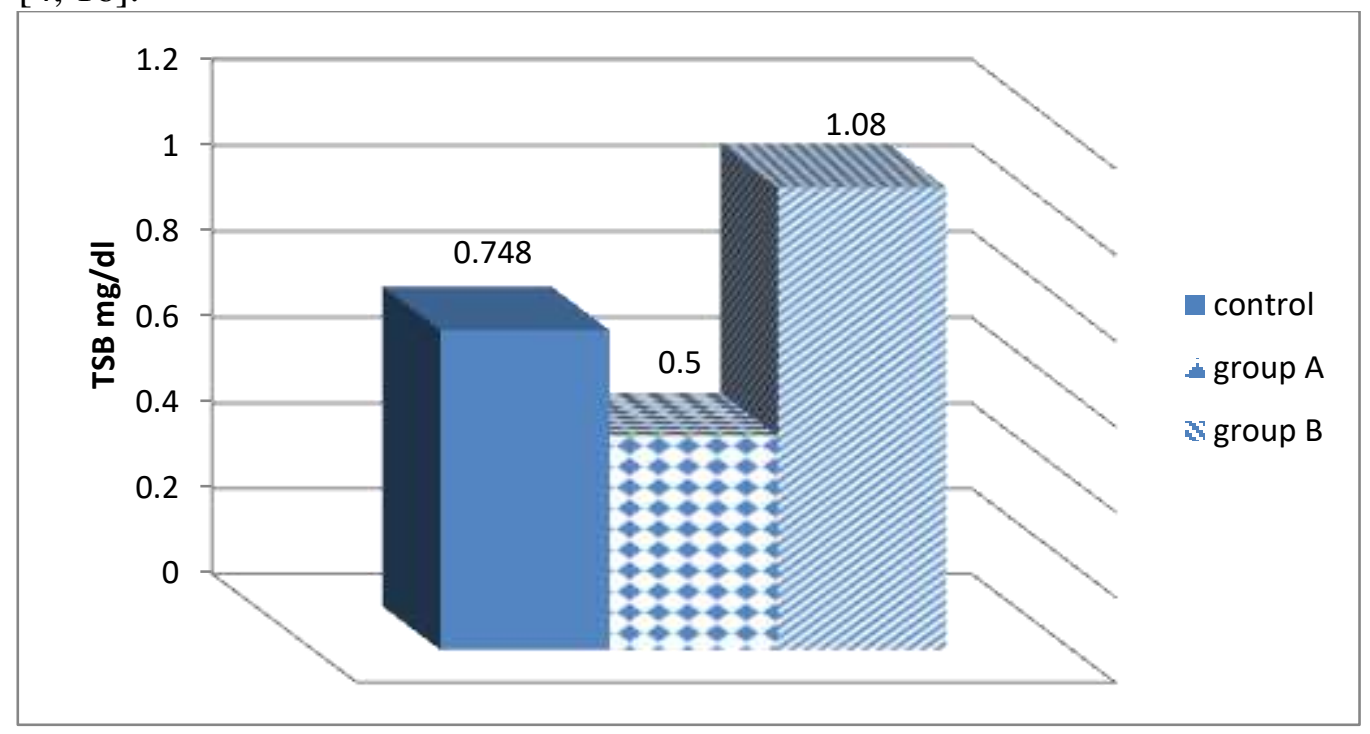

Figure 6-Comparisons in the TSB levels between workers with different working durations in diesel generators(less and more than 10 years) and the control group in Baghdad City, Iraq

The current study additionally shows that long periods of exposure to mild levels of diesel engine exhaust caused a decreased albumin level in group B, while this level was increased in group A, as compared with the control group (Figure 7). Gerlofs-Nijland et al. [17] reported that the exposure to diesel exhaust for many years leads to increased levels of tumor necrosis factor $\alpha(\mathrm{TNF} \alpha)$ and interleukin alpha (IL-1 $\alpha)$ in the striatum of rat brain. The exposure to petrol or diesel engine exhausts may increase the risk of lung cancer and neurological conditions in humans [18].

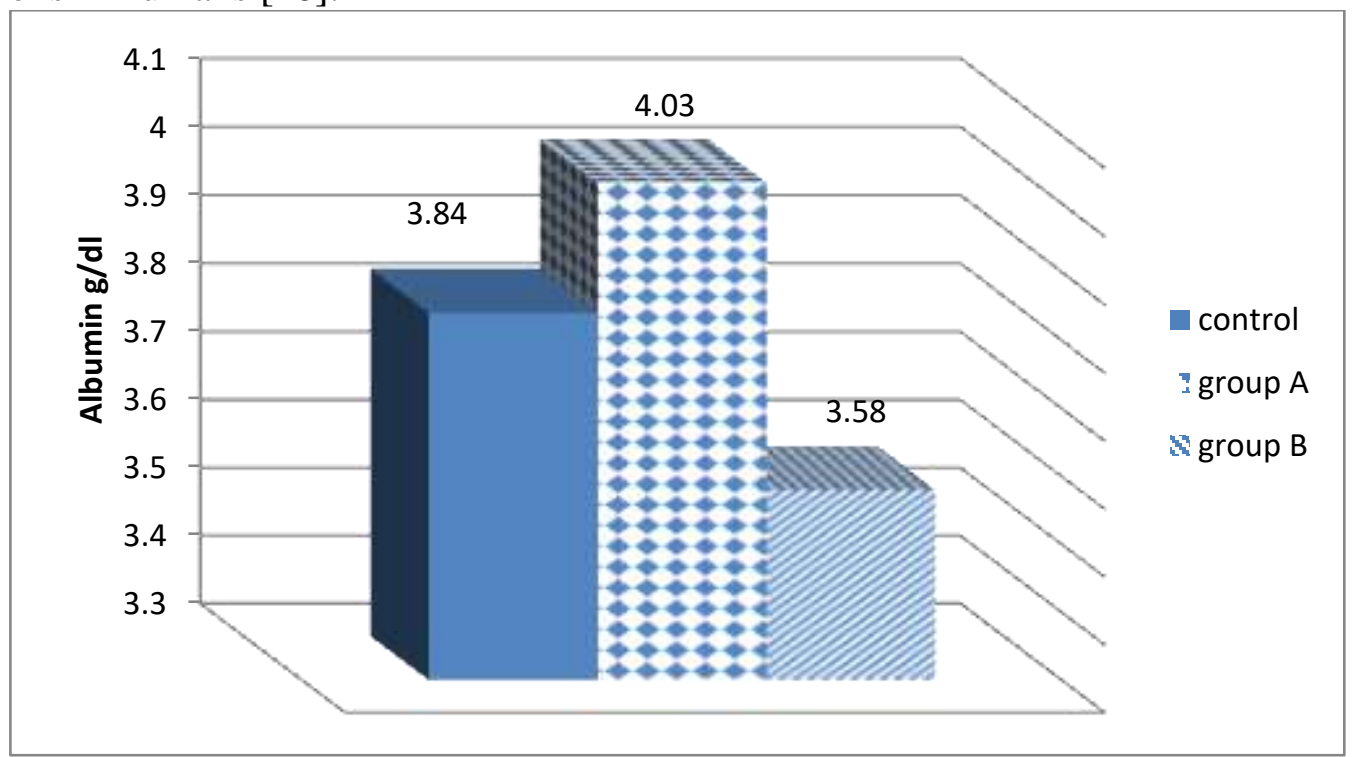

Figure 7-Comparisons in the serum albumin levels between workers with different working durations in diesel generators and the control group in Baghdad City, Iraq

Moreover, the results in Figure 8 show that GFR level in the blood was significantly lower in groups A and B compared with the control group.

The severity of this disease is associated with the value of GFR i, and the relationship is inverse between them; when GFR is diminished, it will lead to an increase in the severity of 
kidney failure disease. A human is considered healthy when the nephritic function, calculated by GFR, is $\sim 125 \mathrm{~mL} / \mathrm{min}$.

. Both creatinine and urea concentrations are increased in the blood and decreased in the urine as the GFR is decreased [9].

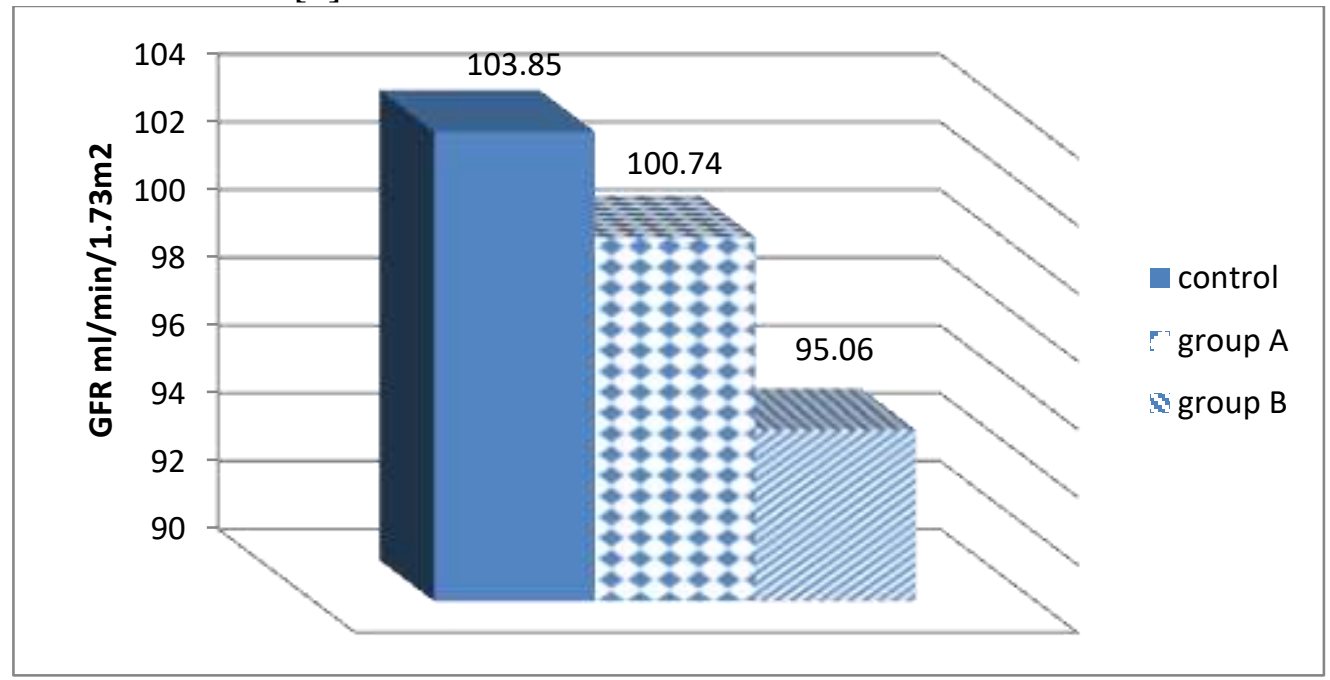

Figure 8-Comparisons in the serum GFR levels between workers with different working durations in diesel generators and the control group in Baghdad City, Iraq

According to the present results, the prolonged exposure (over 10 years) of workers to the petrochemical pollutants from generator fumes will have a more potential effects in different organs (liver and kidney), as reflected by the increase in the levels of creatinine, urea, AlP, GOT, and GPT and the decrease in the levels of TSB and GFR.

\section{References}

[1] M.N. Chukwu, and E.A. Adams, "Effect of Generator (Exhaust) Fumes on the Growth and Development of Lycopersicum esculentus (Tomato)". J. Appl. Sci. Environ. Manage. vol. 20,no.2, pp. $335-340,2016$

[2] W. John, L. Wargo, N. Alderman and D. Brown, "The Harmful Effects of Vehicle Exhaust. A case for Policy change". Environment and Human Health. Inc.2006

[3] Z.Tong, and K.M. Zhang,"The near-source impacts of diesel backup generators in urban environments", Atmospheric Environment, vol.109, pp. 262-271, 2015.

[4] P.J.Tsai, T.S.Shih, H.L.Chen,W.J. Lee,C.H. Lai, S.H. Liou, "Urinary 1- hydroxypyrene as an indicator for assessing the exposure of booth attendants of a highway toll station to PAHs", Environ Sci Technol. vol. 38, no.1, pp.56-61,2004.

[5] H.N. Macfarland, C.E. Ulrich, C.E. Holdsworth, D.N. Kitchen, and W.H. Halliwell, "A chronic inhalation study with unleaded gasoline vapour", Int. J. Toxicol.vol.3,pp.231-248, 1984.

[6] A. Peters, "Ambient Particulate Matter and the Risk for Cardiovascular Disease Introduction", Prog Cardiovasc Dis. vol.53, no.5, pp.327-33,2011

[7] L.C. Reynolds, and R.J. Richards,"Can Toxicogenomics Provide Information on the Bioreactivity of Diesel Exhaust Particles", Toxicology,vol. 165, pp. 145-152, 2011.

[8] M.E.A. Munzir, S.A.J. Al-Obosi, H.M. Osman, and M.E. Shayoub,"The Effect of Smoking Cigarette on Kidney Functions Among Sudanese Peoples", International Journal of Development Research, vol. 5, no.5, pp.4473-4475, 2015.

[9] M.M. Sood, M. Saeed, V. Lim, F. Cordova, P. Komenda, A. Malik, C. Rigatto, L.A. Shafer, N. Tangri, P.S. Tappia, and S. Zieroth, " The urea-to-creatinine ratio is predictive of worsening kidney function in ambulatory heart failure patients". J Card Fail. vol.21, no.5, pp. 412-18, 2015.

[10] E.A. Nwankwo, B. Nwankwo, and B. Mubi, "Prevalence of impaired kidney in hospitalized hypertensive patients in Maiduguri". Nig. Internet J. Int. Med., vol 6, no.1, pp. 1-7, 2006. 
[11] W.I. Mortada, M.A. Sobh, M.M. EL-Defrawy, and S.E. "Farahat, Study of lead exposure from automobile exhaust as a risk for nephrotoxicity among Traffic Policemen", AM J. Nephrol., vol. 21, pp. 274-279, 2001.

[12] T.H. Ueng, H.W.Wang, Y.P. Huang, C.C. Hung, "Antiestrogenic effects of motorcycle exhaust particulate in MCF-7 human breast cancer cells and immature female rats". Arch Environ Contam Toxicol., vol. 46, no.4, pp. 454-62, 2004.

[13] H.H.Tan, M.I. Fiel, Q. Sun, J. Guo, R.E. Gordon, L.C. Chen, S.L. Friedman, J.A. Odin, J. Allina, "Kupffer cell activation by ambient air particulate matter exposure may exacerbatenon-alcoholic fatty liver disease". Journal of Immunotoxicology, Vol.6, pp.266-275, 2009.

[14] X. Liu, J. Shao, L. Xiang, X. Chen, "Cytotoxic effects and apoptosis induction of atrazine in a grass carp (Ctenopharyngodon idellus) cell line". Environmental Toxicology, vol.21,no.1,pp.80$89,2006$.

[15] W. H. Y. Hussein, "Assessment of plasma Urea, Creatinine and Uric acid levels among Sudanese Cigarette Smokers (study in Khartoum) State", M.SC thesis in clinical chemistry. University of Science and Technology, Sudan, 2015.

[16] International Agency for Research on Cancer (IARC)," Diesel Engine Exhaust Carcinogenic", Press Release, no. 213, Jun 12, 2012.

[17] M.E. Gerlofs-Nijland, D.V. Berlo, F.R. Cassee1, R.P.F. Schins, K. Wang, and A. Campbell, "Research Effect of prolonged exposure to diesel engine exhaust on proinflammatory markers in different regions of the rat brain". Particle and Fibre Toxicology, vol.7, pp.1-10,2010.

[18] S.M.J. MohanKumar, A. Campbell, M. Block, B. Veronesi, "Particulate matter, oxidative stress and neurotoxocity". Neurotoxicology, vol.29, pp. 479-488, 2008. 